\title{
Review of Brazilian Eriococcidae (Hemiptera: Coccomorpha) with redescription of a Neotectococcus and two Acanthococcus species and description of a new species
}

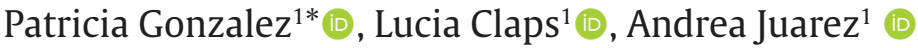 \\ ${ }^{1}$ Universidad Nacional de Tucumán. Facultad de Ciencias Naturales e Instituto Miguel Lillo, Instituto Superior de Entomología \\ "Dr. Abraham Willink", Tucumán, Argentina; \\ urn:lsid:zoobank.org:pub:86587B94-792F-4308-B70A-3C4B36537555
}

\section{A R T I C L E I N F O}

Article history:

Received 11 October 2018

Accepted 15 January 2020

Available online 23 March 2020

Associate Editor: Takumasa Kondo

Key words:

Acanthococcus

Key

Neotectococcus

Neotropical

\begin{abstract}
A B S T R A C T
The Eriococcidae (Hemiptera: Coccomorpha), are known as felt scales and a family with a worldwide distribution, represented by 33 genera and 92 species in the Neotropical region. Some of these species induce galls on their host plants. The aim of this study is to review and update all the information currently known about the biodiversity of Eriococcidae in Brazil and to redescribe and illustrate Acanthococcus lanatus (Hempel), Acanthococcus campinensis (Hempel) and Neotectococcus lenticularis Hempel because Hempel's original descriptions are very brief and he made no illustrations, and to describe a new species of Acanthococcus Signoret, Acanthococcus papaveroi González, Claps \& Juárez sp. nov. A dichotomous key to the Acanthococcus species from Brazil is presented and an updated table of the Eriococcidae known from this country is included, with 34 species and 16 genera in total, each with distribution, host data and type depositories of each species.
\end{abstract}

\section{Introduction}

The Eriococcidae (Hemiptera: Coccomorpha) are generally referred to as the "felt scales" because many species have a felt-like waxy cover that protect their bodies. The family is distributed worldwide, but is mainly found in the Southern Hemisphere (Miller and Gimpel, 2000). The family includes 33 genera and 92 species from the Neotropical region (Caballero et al., 2019) of which 16 genera and 33 species have been reported from Brazil (García Morales et al., 2016). Many of these species induce galls on their host plants (Foldi and Kozár, 2007). Extensive early studies by Adolph Hempel described Coccomorpha from Brazil (Hempel, 1900a, 1900b, 1932, 1934, 1937). Other publications on the taxonomy of Brazilian Eriococcidae include Ferris (1957), who reviewed and illustrated some of the genera and species, and Claps (1993) who listed the Coccomorpha, including eriococcid specimens deposited in collections from that country. Hodgson et al. (2004) presented a dichotomous key to genera of Neotropical Eriococcidae genera and a review of Pseudotectococcus Hempel. Foldi and Kozár (2007) and Kozár and Konczné Benedicty (2008) described new Neotropical

\footnotetext{
* Corresponding author.

E-mail: mopagon2004@yahoo.com.ar
}

genera and species. Hodgson and Miller (2010) reviewed the genera of Eriococcidae from South America and redescribed some of the species. Hodgson et al. (2011, 2013) described several new genera that induce galls, González and Claps (2011, 2013) studied Neotropical species, and Kondo et al. (2016) revised the genus Capulinia Signoret. All the above studies included species from Brazil.

The aim of this study is to review and update taxonomic information on the Eriococcidae from Brazil, to redescribe and illustrate three of the species described by Hempel $(1932,1937)$ because Hempel's original descriptions are very brief, and he made no illustrations. In addition, one new species is described and a key to species of Acanthococcus known from Brazil is included.

\section{Materials and Methods}

The collections at the Museu de Zoología da Universidade de São Paulo (MZSP), Instituto Biológico de São Paulo (IB), and Universidade Federal do Paraná (DCMP), Curitiba, Brazil, were studied. Some holotypes were not found, and we conclude that they are lost. 
Illustrations are presented with the right half the ventral surface and the left half the dorsal surface; enlargements of certain structures are given around the perimeter of the central drawing and are not proportional to each other. A Camera Lucida attached to an Olympus BX51 compound microscope with 40x and 100x magnifications was used to prepare illustrations. Measurements (width and length) are maximum dimensions and are expressed in $\mathrm{mm}$ (millimeters) and $\mu \mathrm{m}$ (micrometers), the range corresponds to all the specimens studied.

Microtubular ducts were recognized according to González (2008): Microtubular duct: “Type B" (Figs. 1-3): with a narrow, undivided vestibule (ductule), with the inner end rounded and a simple outer orifice; "Type A" (Fig. 2) with a broad vestibule, longitudinally divided by a median septum, the inner end with two protuberances and with a simple outer orifice. Foldi and Kozár (2007) illustrate a microtubular duct similar to "Type A" microtubular ducts.

A table of eriococcid species from Brazil, including the depository of type material, geographic distribution and host plant families (Table 1) is presented, based on the studied specimens and literature reviewed, with some data from ScaleNet (García Morales et al., 2016).

List of abbreviations (Miller and Gimpel, 2000; Evenhuis, 2018) for depositories of type material:

BHMH: Museu de Historia Natural, Universidade Federal de Minas Gerais, Belo Horizonte, Brazil.

DCMP: Universidade Federal do Paraná, Paraná, Curitiba, Brazil.

IB: Instituto Biologico de São Paulo, Brazil.

MEUC: Santiago, Universidad de Chile, Chile.

MNHN: Muséum National d'Histoire Naturelle, Paris, France.

MNHU: Museum fúr Naturkunde der Humboldt Universität zu Berlin, Germany.

MZSP: Museu de Zoologia da Universidade de São Paulo, Brazil.

NHMUK: The Natural History Museum [formerly British Museum (Natural History)] United Kingdom, London.

NZAC: New Zealand Arthropod Collection, Auckland, New Zealand.

PPI: Plant Protection Institute, Hungarian Academy of Sciences, Budapest, Hungary.

SDEI: Müncheberg, Senckenberg Deutsches Entomologisches Institut, Germany.

UCDC: The. Bohart Museum of Entomology, University of California, Davis, California, USA.

USNM: National Museum of Natural History Smithsonian Institution [formerly, United States National Museum] USA, Washington D.C.

\section{Results}

\section{Acanthococcus campinensis (Hempel, 1937) (Fig. 1)}

Eriococcus campinensis Hempel, 1937: 5-6; Hoy, 1963:78; Lepage, 1938:379; Silva et al., 1968:159; Stoetzel \& Miller, 1979: 9; Miller \& Gimpel, 2000: 154.

Acanthococcus campinensis; Miller \& Gimpel, 1996: 599. Change of combination; Hodgson \& Miller, 2010: 99; García Morales et al., 2016.

Type material. Holotype: Female, Brazil, São Paulo, Campinas, on Tephrosia candida, 30/X/1934. Deposited in IB, type № 361 (Hempel, 1937), not found. Part of the type series is in the USNM (Miller and Gimpel, 2000), not studied.

Material examined. No data, but labelled Eriococcus campinensis Hempel, 9 adult females ( 4 in good condition) and 5 first-instar nymphs, IB.

Appearance in life. The female forms a thick, felted, non-sticky sac, with the rear end facing upwards and provided with a small circular

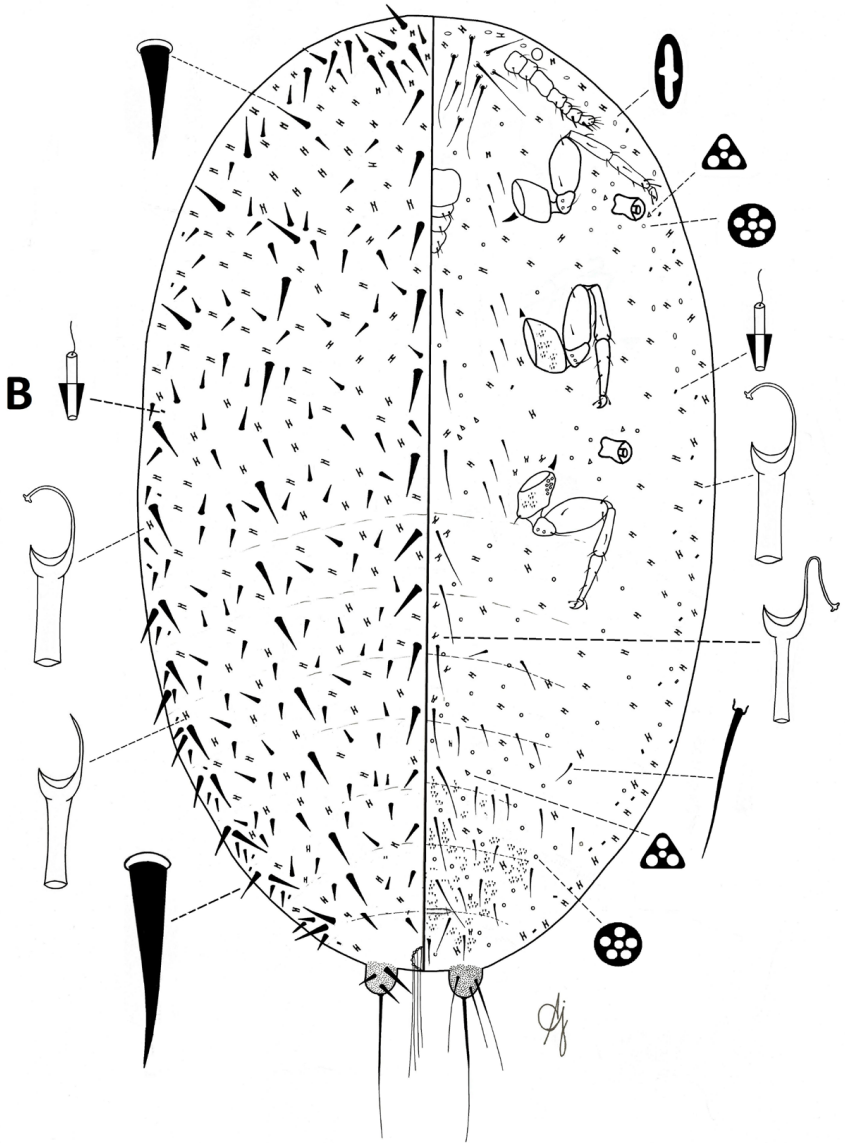

Figure 1: Acanthococcus campinensis (Hempel). Adult female. B, microtubular duct of type $\mathrm{B}$.

hole. Some transverse striae are barely perceptible. The sac measures about $3 \mathrm{~mm}$ in length and $2.2 \mathrm{~mm}$ in width (Hempel, 1937).

Species diagnosis. Microtubular ducts sparse, present only along margin on both surfaces; marginal setae differentiated from dorsal setae on abdominal segments; metacoxae with 6-10 dorsal pores; prothoracic tibia with 6 setae; anal lobes each with 3-4 ventral flagellate setae and a long, narrow inner anterior dorsal setae.

\section{Redescription.}

Adult female: body oval in outline; $1.5-2.0 \mathrm{~mm}$ long, $1.1-1.4 \mathrm{~mm}$ wide. Anal lobes enlarged, sclerotised; each 65-72 $\mu \mathrm{m}$ long, $48-57 \mu \mathrm{m}$ wide; with 3 conical setae on dorsal surface, as follows: inner anterior seta long and narrow, about 62-72 $\mu \mathrm{m}$, inner posterior seta about 43-50 $\mu \mathrm{m}$ and outer seta about 26-40 $\mu \mathrm{m}$; ventral surface with 3-4 flagellate setae on ventral surface each $48-163 \mu \mathrm{m}$, plus an apical seta about 240-248 $\mu \mathrm{m}$ long. Medial plate absent.

Dorsum: with abundant conical setae, each slightly curved, with an acute apex; variable in size, smallest about $22 \mu \mathrm{m}$ long, arranged in transversal bands on all segments; longest about $72 \mu \mathrm{m}$ long, distributed in longitudinal lines along surface in submarginal, lateral and medial regions, the latter reaching posteriorly as far as abdominal segment IV. Macrotubular ducts numerous, symmetrical, present over entire surface, each 12-22 $\mu \mathrm{m}$ long, 4-5 $\mu \mathrm{m}$ wide, some with internal duct with terminal gland. Microtubular ducts type B, 5-7 $\mu \mathrm{m}$ long, $2 \mu \mathrm{m}$ wide, sparse on margin, absent from the rest of dorsum. Anal ring with eight setae, each 96-156 $\mu \mathrm{m}$ long, with single row of pores. 
Table 1. List of species of Eriococcidae reported from Brazil.

\begin{tabular}{|c|c|c|c|c|c|}
\hline Genera & Species & Author & Host & Distribution & Collections \\
\hline \multirow[t]{14}{*}{ Acanthococcus } & campinensis & (Hempel) & Fabaceae & Brazil & $\begin{array}{l}\text { IB not found } \\
\text { Part in USNM }\end{array}$ \\
\hline & christopherus & (Foldi \& Kozár) & Myrtaceae & Brazil & $\begin{array}{c}\text { MNHN } \\
\text { Paratype in PPI }\end{array}$ \\
\hline & coccineus & (Cockerell) & Cactaceae & Cosmopolitan & USNM \\
\hline & coffeae & (Hempel) & Rubiaceae & Brazil & MZSP \\
\hline & dubius & (Cockerell) & Polyphagous & Cosmopolitan & MNHN \\
\hline & jorgenseni & (Morrison) & $\begin{array}{c}\text { Asteraceae, Lauraceae, } \\
\text { Myrtaceae }\end{array}$ & Argentina, Brazil & $\begin{array}{l}\text { USNM } \\
\text { PPI } \\
\text { NHMUK }\end{array}$ \\
\hline & lanatus & (Hempel) & Myrtaceae & Brazil & MZSP \\
\hline & longisetosus & (Foldi \& Kozár) & Annonaceae & Brazil & MNHN \\
\hline & maximus & (Foldi \& Kozár) & Myrtaceae & $\begin{array}{l}\text { Brazil, Paraguay, } \\
\text { Venezuela }\end{array}$ & $\begin{array}{c}\text { MNHN } \\
\text { Paratypes in PPI, BMNH }\end{array}$ \\
\hline & microspinus & Kozár \& Konczné Benedicty & Unknown host & Brazil & $\begin{array}{l}\text { SDEI } \\
\text { Paratypes in PPI }\end{array}$ \\
\hline & papaveroi & $\begin{array}{c}\text { González, Claps \& Juárez } \\
\text { sp. nov }\end{array}$ & Unknown host & Brazil & IB \\
\hline & perplexus & (Hempel) & Myrtaceae & Brazil & $\begin{array}{c}\text { Syntypes in IB, MNHN, MNHU } \\
\text { Cotypes in USNM }\end{array}$ \\
\hline & piptadeniae & (Hempel) & Fabaceae & Brazil & IB \\
\hline & venezuelaensis & (Foldi \& Kozár) & $\begin{array}{c}\text { Asteraceae, Fabaceae, } \\
\text { Myrtaceae }\end{array}$ & Brazil, Venezuela & $\begin{array}{l}\text { MNHN } \\
\text { Paratypes in PPI }\end{array}$ \\
\hline Aculeococcus & morrisoni & Lepage & Unknown host & Brazil & IB \\
\hline \multirow[t]{4}{*}{ Apiococcus } & asperatus & Hempel & Myrtaceae & Brazil & $\begin{array}{c}\text { MZSP } \\
\text { Syntypes in USNM }\end{array}$ \\
\hline & globossus & Hempel & Myrtaceae & Brazil & MZSP \\
\hline & gregarius & Hempel & Myrtaceae & Brazil & $\begin{array}{c}\text { MZSP } \\
\text { Syntype in USNM }\end{array}$ \\
\hline & singularis & Hempel & Myrtaceae & Brazil & $\begin{array}{c}\text { MZSP } \\
\text { Syntypes in USNM }\end{array}$ \\
\hline Bystracoccus & mataybae & Hodgson, Isaias \& Oliveira & Sapindaceae & Brazil & UFMG \\
\hline \multirow[t]{2}{*}{ Capulinia } & crateraformis & Hempel & Myrtaceae & Brazil & $\begin{array}{c}\text { MNHN } \\
\text { MNHU, USNM }\end{array}$ \\
\hline & jaboticabae & Ihering & Myrtaceae & Brazil & $\begin{array}{c}\text { MNHN } \\
\text { MNHU } \\
\text { Cotype in USNM }\end{array}$ \\
\hline Carpochloroides & viridis & Cockerell & Myrtaceae & Brazil & $\begin{array}{l}\text { USNM, MNHN } \\
\text { IB }\end{array}$ \\
\hline Eriogallococcus & isaias & Hodgson \& Magalhães & Malvaceae & Brazil & BHMH \\
\hline \multirow[t]{2}{*}{ Hempelicoccus } & brasiliensis & (Cockerell) & Asteraceae & Brazil & MZSP, NHMUK, USNM, MNHU \\
\hline & paranaensis & (Foldi \& Kozar) & Asteraceae & Brazil & $\begin{array}{c}\text { MNHN } \\
\text { Paratype in PPI }\end{array}$ \\
\hline Madarococcus & rhadinothrix & (Miller \& González) & Nothofagaceae & $\begin{array}{l}\text { Argentina, } \\
\text { Brazil, Chile }\end{array}$ & $\begin{array}{c}\text { MEUC } \\
\text { Paratypes in BMNH, UCDC, } \\
\text { USNM }\end{array}$ \\
\hline Melzeria & horni & Green & Unknown host & Brazil & $\begin{array}{c}\text { BMNH } \\
\text { Paratypes in USNM }\end{array}$ \\
\hline Neotectococcus & lenticularis & Hempel & Unknown host & Brazil & IB \\
\hline Pseudocapulinia & lanosa & Hempel & Unknown host & Brazil & MZSP \\
\hline Pseudotectococcus & anonae & Hempel & Annonaceae & Brazil & MZSP \\
\hline \multirow[t]{2}{*}{ Rhizococcus } & coccineus & (Cockerell) & Cactaceae & Cosmopolitan & USNM \\
\hline & rolliniae & Hodgson \& Gonçalves & Annonaceae & Brazil & MZSP \\
\hline Tectococcus & ovatus & Hempel & Myrtaceae, Thymelaeaceae & Brazil & $\begin{array}{l}\text { MZSP, MNHU, Cotypes in } \\
\text { USNM }\end{array}$ \\
\hline Uhleria & araucariae & (Maskell) & $\begin{array}{c}\text { Araucariaceae, Cupressaceae, } \\
\text { Cycadaceae, Myrtaceae, } \\
\text { Pinaceae, Poaceae }\end{array}$ & Cosmopolitan & NZAC, USNM \\
\hline
\end{tabular}

Margin: setae conical, straight; each abdominal segment with 2-3 setae, each about 29-31 $\mu \mathrm{m}$, with one of each group larger about $60 \mu \mathrm{m}$ long. Marginal setae undifferentiated from dorsal setae on thoracic and cephalic regions.

Venter: setae flagellate, of variable length, with 1 or 2 setae medially in each segment each 53-84 $\mu \mathrm{m}$, also with numerous small setae each
$20-25 \mu \mathrm{m}$, on midline of abdominal segments IV-VII, and in groups near the three pairs of coxae. Flagellate setae present between antennae, variable in size, with 4 pairs each $60-80 \mu \mathrm{m}$ long and 5 or 6 shorter pairs, each 19-22 $\mu \mathrm{m}$ long. Enlarged setae absent. Suranal flagellate setae present, each 72-100 $\mu \mathrm{m}$ long. Microspines present on medial and submedial regions on last abdominal segments. Quinquelocular pores, each about $5 \mu \mathrm{m}$ diameter, sparse on abdominal segments, 
medially on thorax, and near each spiracle; trilocular pores sparse, present medially in thoracic region and near spiracles. Cruciform pores present submarginally and laterally in cephalic and pro and mesothoracic regions. Macrotubular ducts symmetrical, similar in size to those on dorsum, present along margin and sparse over rest of venter; other macrotubular ducts with broad cup but narrow outer ductule, each $2 \mu \mathrm{m}$ wide, $10 \mu \mathrm{m}$ long, present medially on abdominal segments II-IV and near metacoxae. Microtubular ducts type B restricted to near margin. Legs well developed, plump; lengths $(\mu \mathrm{m})$ : prothoracic legs: coxa each 108-120; trochanter + femur 192-198; tibia each 108-118, with 6 setae; tarsus each 120-128, claw 29-39, with a denticle; mesothoracic legs: coxa 109-132, with ventral microspines; trochanter + femur 204-218; tibia 120-148, with 5 setae; tarsus about 120-148 $\mu \mathrm{m}$; claw about 36-41 $\mu \mathrm{m}$ long, with a denticle; metathoracic legs: coxa about 118-120, with microspines and 6-10 dorsal translucent pores, trochanter + femur each 211-218; femur, without translucent pores; tibia 144-148, with 5 setae; tarsus about 120-148; claw about 48, with a denticle; claw and tarsal digitules of all legs of equal size, with slightly expanded apices. Antennae each 247-277 $\mu \mathrm{m}$ long, with 7 segments, segment III without setae, longest, about double length of segment IV; flagellate setae present on all other segments; fleshy setae present on apical 3 segments. Frontal lobes absent. Labium 158-168 $\mu \mathrm{m}$ long, 3 segmented, basal segment with 2 pairs of setae. Peritreme of spiracles $31-38 \mu \mathrm{m}$ wide. Anal tube unsclerotised.

Observations. On two specimens, the long medial setae on dorsum occur posteriorly, as far as abdominal segment VII although this is not entirely certain because the specimens are not completely flattened. Also, one specimen has antennal segments III and IV of equal length.

Distribution. Brazil.

Comments. Acanthococcus campinensis differs from A. christopherus Foldi \& Kozár (2007), from Brazil, in having (character-states of A. christopherus in brackets taken from Foldi and Kozár, 2007): (i) smallest dorsal setae arranged in transversal bands in all segments, largest dorsal setae distributed in longitudinal lines in submarginal, lateral and medial regions, the latter reaching as far as abdominal segment IV (dorsal setae arranged in 2 longitudinal medial bands and 9 transverse rows), ii) frontal lobes absent (present), iii) metathoracic coxae with 6-10 translucent pores and femur without pores (coxae with 90-115 pores and femur with 10-15 pores), iv) trilocular pores sparse, in medial thoracic region and near spiracles (not described, apparently not present), v) microtubular ducts restricted to margin on both surfaces (scattered throughout on dorsal surface, absent on ventral surface), vi) ventral macrotubular ducts with a broad cup, narrow, present (not described, apparently not present), and vii) submarginal and lateral cruciform pores present in cephalic and pro and mesothoracic regions (in a submarginal band from head to about abdominal segment III).

Acanthococcus campinensis resembles A. gracielae González \& Claps, 2011, A. granarae González \& Claps, 2011, A. piptadeniae (Hempel, 1937), A. dubius (Cockerell, 1896) and A. arctostaphyli (Ferris, 1955) [considered Eriococcus in, García Morales et al., 2016, but this species was transferred to Acanthococcus by Miller \& Miller, 1992]; the latter two species are from the Nearctic region; all of these species have six setae on the prothoracic tibiae and five setae on meso- and metathoracic tibiae.

Acanthococcus campinensis differs from $A$. gracielae in having (character-states of $A$. gracielae in brackets taken from González and Claps, 2011): (i) dorsal setae with an acute apex (with rounded apex), (ii) anal lobes each with 3-4 ventral setae (2 setae), (iii) metacoxae each with $6-10$ pores (about 50 pores), and (iv) anal lobes each with a large, narrow inner anterior dorsal seta (inner anterior seta smaller than other setae). Acanthococcus campinensis differs from A. granarae in having (character-states of $A$. granarae in brackets taken from González and Claps, 2011): (i) metacoxae each with 6-10 pores (about 40 pores), (ii) anal lobes each with large, narrow inner anterior dorsal seta (outer seta larger), and (iii) frontal lobes absent (present). Acanthococcus campinensis differs from $A$. piptadeniae in having (character-states of $A$. piptadeniae in brackets taken from Hempel, 1937): (i) quinquelocular and trilocular pores sparse on ventral surface (numerous), (ii) microtubular ducts sparse and restricted to margin (numerous on both surfaces), and (iii) anal lobes each with large, narrow inner anterior dorsal seta (inner anterior seta smaller than the others).

Acanthococcus campinensis differs from A. dubius, in having (character-states of $A$. dubius in brackets taken from Miller and Miller, 1992): (i) quinquelocular pores sparse on abdomen (abundant), (ii) metacoxae with 6-10 dorsal pores, 0 ventral pores (13-38 dorsal pores and 0-24 ventral pores), (iii) anal lobes each with inner anterior dorsal setae larger than other two dorsal setae (inner anterior setae smaller than the others), and iv) dorsal microtubular ducts restricted to the margin (all over the dorsal surface). Acanthococcus campinensis differs from $A$. arctostaphyli (Ferris), in having (character states of $A$. arctostaphyli in brackets taken from Miller \& Miller, 1992): (i) quinquelocular pores sparse on abdominal segments (numerous), (ii) anal lobes each with inner anterior dorsal seta larger than others dorsal setae (dorsal setae all equal in size), and (ii) metacoxae each with 6-10 dorsal pores (16-96 dorsal pores).

\section{Acanthococcus lanatus (Hempel, 1932) (Fig. 2)}

Eriococcus lanatus Hempel, 1932: 317-318; Costa Lima, 1936: 178; Lepage 1938: 279; Hoy, 1963: 99; Silva et al., 1968: 159; Miller \& Gimpel, 2000: 253.

Nidularia lanatus; Lindinger, 1933: 116. Change of combination change.

Acanthococcus lanatus; Miller \& Gimpel, 1996: 601. Change of combination; Hodgson \& Miller, 2010: 100; García Morales et al. (2016).

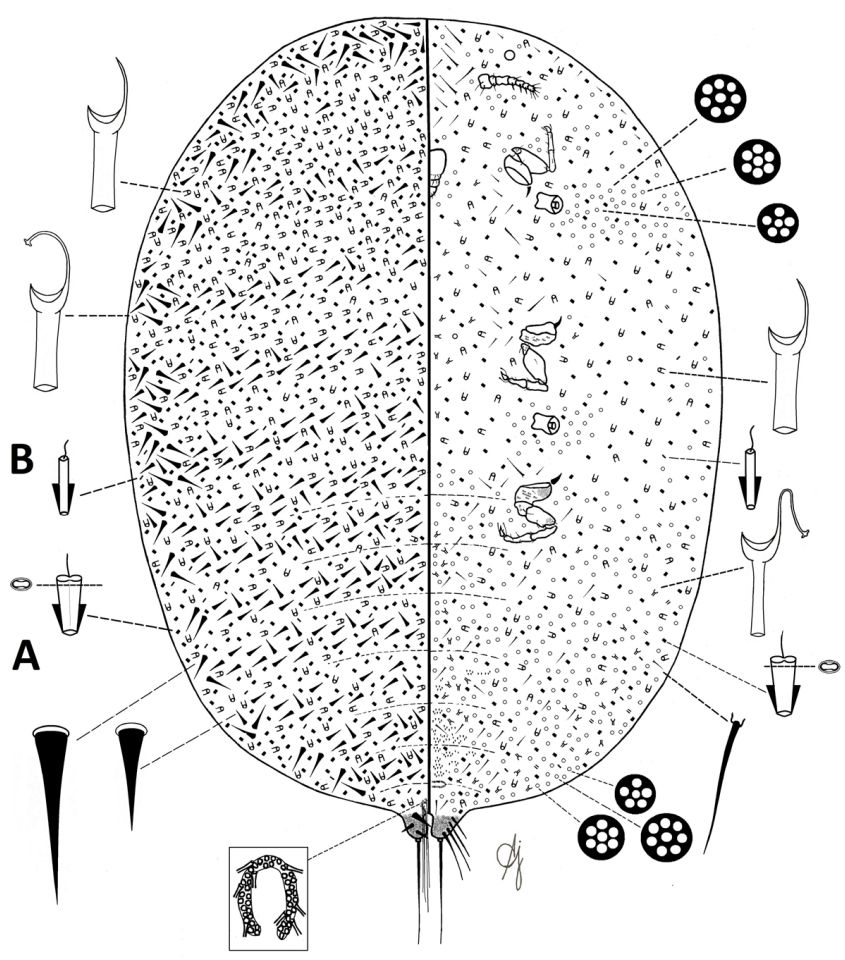

Figure 2: Acanthococcus lanatus (Hempel). Adult female. A, microtubular duct of type A; B, microtubular duct of type B. 
Type material. Holotype: Female, Brazil, São Paulo, Amaro, on Eugenia pitanga, 30/X/1934, J. Britto \& R. Drummond cols. Deposited in MZSP (Hempel, 1932).

Material examined. Eriococcus lanatus, H. Drummond coll. Det. A. Hempel. R. 431. Dupl., 8 adult females (good condition), MZSP.

Appearance in life. The female is wholly enveloped by a layer of white waxy, floccose, sub-spherical in shape, 5-6 $\mathrm{mm}$ in diameter, without orifice in the apex, and usually fixed in the axils of the leaves and branches, sometimes isolated; most frequently the individuals are grouped in number of 2-8 or more (Hempel, 1932).

Species diagnosis. Microtubular ducts abundant on both surfaces; metacoxae each with 40-50 (20-30 dorsal and 15-20 ventral) translucent pores; anal lobes each with 4 ventral setae; anal ring with 2 rows of pores; spiracles large in comparison to legs, each about same size as a coxa.

\section{Redescription.}

Adult female: body oval in outline; 3.1-3.7 mm long, 1.7-2.8 mm wide. Anal lobes enlarged, sclerotised; each 96-120 $\mu \mathrm{m}$ long, 67-84 $\mu \mathrm{m}$ wide; with 3 conical setae on dorsal surface as follows: inner anterior seta $60-65 \mu \mathrm{m}$ long, inner posterior seta and outer setae both $48-55 \mu \mathrm{m}$ long; with 4 flagellate setae on ventral surface each 36-120 $\mu \mathrm{m}$ long; apical seta each 233-235 $\mu \mathrm{m}$ long. Medial plate absent.

Dorsum: with numerous conical setae, each straight, with an acute apex, length varying from 33-50 $\mu \mathrm{m}$, arranged in transverse bands across all segments; larger setae, each 70-80 $\mu \mathrm{m}$ long, present along body submargin, with 2 setae on each abdominal segment, but more numerous in thoracic and cephalic regions. Macrotubular ducts abundant throughout, symmetrical, varying in size, some about $7 \mu \mathrm{m}$ wide, $14 \mu \mathrm{m}$ long; others about $5 \mu \mathrm{m}$ wide, $22 \mu \mathrm{m}$ long; also, some with an internal ductule with a terminal gland. Microtubular ducts, type A, bilocular, each 5-7 $\mu \mathrm{m}$ long, $2 \mu \mathrm{m}$ wide, very abundant throughout. Microtubular ducts, type B, scattered, sparse throughout. Anal ring with 8 setae, each $125-132 \mu \mathrm{m}$ long, with 2 almost complete rows of pores.

Margin: setae undifferentiated from dorsal setae.

Venter: setae flagellate of variable lengths, each $29-50 \mu \mathrm{m}$, sparse on abdominal segments and near each coxa. Flagellate setae between antennae of variable lengths, with 4 pairs each $48-72 \mu \mathrm{m}$ and 5 or 6 shorter pairs each $22-36 \mu \mathrm{m}$. Enlarged setae absent. Suranal setae flagellate, not measurable. Microspines present on medial area of posterior abdominal segments. Quinquelocular pores each about $5 \mu \mathrm{m}$ diameter, throughout venter; numerous in segmental bands on abdominal segments, also present in a band of 40-50 pores extending from each anterior spiracle to margin and in a group around each posterior spiracle; 6-locular and 7-locular pores sparse, near spiracles and abdominal segments; trilocular and cruciform pores absent. Macrotubular ducts symmetrical, similar to those on dorsum, numerous over entire surface; other macrotubular ducts with broad cup but narrow outer ductule, each about $3 \mu \mathrm{m}$ wide, 12-16 $\mu \mathrm{m}$ long, numerous (about 30) on medial and lateral areas on abdominal and thoracic segments, extending to base of procoxae. Microtubular ducts similar to those on dorsum, abundant throughout. Legs well developed, plump; lengths $(\mu \mathrm{m})$ : prothoracic coxae each 96-108; trochanter + femur each 192-216; tibia each 103-108, with 5 setae; tarsus each 96-108, claw 36, with a denticle; mesothoracic legs: each coxa 120-144, with ventral microspines; trochanter + femur each 191-221; tibia each about 103-113, with 4 setae; tarsus each 108-113; claw 36-41, with a denticle; metathoracic legs: each coxa 120-156, with microspines, plus 40-50 translucent pores (20-30 dorsal pores and 15-20 ventral pores); trochanter + femur each 204-230; femur with 5-7 marginal pores; tibia each about 115-122, with 5 setae; tarsus each 115-122; claw 36-43, with a denticle; claw and tarsal digitules of equal size, with slightly expanded apices. Antennae each 252-264 $\mu \mathrm{m}$ long, with
7 segments, segment III, without setae, longest, almost twice length of segment IV; flagellate setae present on all other segments; fleshy setae present on apical 3 segments. Frontal lobes absent. Labium 144- $192 \mu \mathrm{m}$ long, 3 segmented, basal segment with 2 pairs of setae. Peritreme of spiracles 68-99 $\mu \mathrm{m}$ wide. Anal tube unsclerotised.

\section{Distribution. Brazil}

Comments. Acanthococcus lanatus differs from A. christopherus Foldi \& Kozár, which was described also from Eugenia in Brazil, in having (character-states of $A$. christopherus in brackets taken from Foldi and Kozár, 2007): (i) dorsal setae arranged in transverse bands across all segments; larger setae present along body submargin, (dorsal setae arranged in 2 longitudinal medial bands and 9 transverse rows), ii) metathoracic coxae with 40-50 translucent pores and femur with 5-7 pores (coxae with $90-115$ pores and femur with $10-15$ pores), iii) quinquelocular pores throughout venter; numerous in segmental bands on abdominal segments, also present in a band of 40-50 pores extending from each anterior spiracle to margin and in a group around each posterior spiracle (not present in a band from each anterior spiracle to margin), iv) microtubular ducts abundant throughout on both surfaces (scattered throughout on dorsal surface, absent on ventral surface), and v) anal ring with 2 almost complete rows of pores (with one row).

Also A. lanatus resembles A. microspinus Kozár and Konczné Benedicty, 2008, A. venezuelaensis Foldi \& Kozár, 2007, and $A$. perplexus (Hempel) from Brazil. However, A. lanatus differs from $A$. microspinus, in having (character-states of $A$. microspinus in brackets taken from Kozár and Konczné Benedicty, 2008): i) dorsal microtubular ducts very abundant throughout (scattered among dorsal surface, one present on the base of spines), ii) metacoxae with 40-50 translucent pores (small number of pores), iii); middorsal setae on midline of the three penultimate segments about the same size as others on dorsum (setae very short), and iv) frontal lobes absent (present). Acanthococcus lanatus differs from $A$. venezuelaensis, in having (character-states of $A$. venezuelaensis in brackets taken from Foldi and Kozár, 2007): i) frontal lobes absent (present), ii) meso and metacoxae with microspines (all coxae with microspines), iii) metacoxa with plus 40-50 translucent pores (10-12 pores), and iv) cruciform pores absent (present on margin on abdomen and on submargin on thorax).

Acanthococcus lanatus differs from A. perplexus in having (character-states of $A$. perplexus in brackets taken from Kozár and Konczné Benedicty, 2008): i) larger dorsal setae present along body submargin (larger setae not arranged on submargin), ii) frontal lobes absent (present), iii) quinquelocular pores present in a band of 40-50 pores extending from each anterior spiracle to margin and in a group around each posterior spiracle (not with this distribution, distributed in rare bands on all segments of abdomen and thorax), and iv) metacoxae with 40-50 translucent pores not grouped (small number of big pores in groups).

Acanthococcus lanatus resembles Eriococcus gerbergi McDaniel, 1959, in having abundant microtubular ducts on both surfaces, but differs in having (character- states of E. gerbergi in brackets taken from Miller and Miller, 1992): (i) dorsal setae each with an acute apex (truncate apex),(ii) cruciform pores absent (present along body margin), and (iii) ventral enlarged setae absent (present near body margin from abdominal segment VII through head).

Acanthococcus lanatus has an anal ring with two rows of pores; this character state has been reported only on eriococcid species associated with Nothofagus spp. (Nothofagaceae).

Acanthococcus papaveroiGonzález, Claps \& Juarez sp. nov. (Fig 3).

Material examined. Type material. Holotype: Female, Brazil, São Paulo, unknown host, 26/ IX/1931, P. Fonseca coll. Deposited in IB. Right label: Gab.18. Div. 41.

Appearance in life. Unknown. 


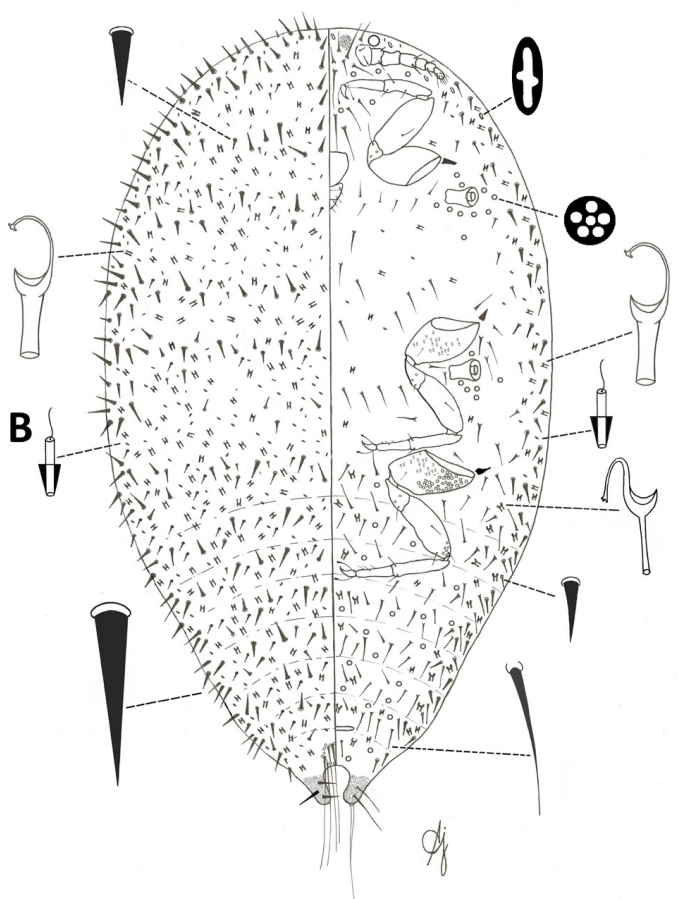

Figure 3: Acanthococcus papaveroi González, Claps \& Juárez sp. nov. Adult female. $\mathrm{B}$, microtubular duct of type $\mathrm{B}$.

Species diagnosis. Macrotubular ducts and type B microtubular ducts numerous throughout dorsal surface but restricted to margin on ventral surface; metacoxae with 30-35 (30 dorsal and 0-5 ventral) translucent pores; anal lobes each with 2 ventral setae; basal segment of labium with one pair of setae; small frontal lobes present.

\section{Description.}

Adult female: body oval in outline; $1.89 \mathrm{~mm}$ long, $1.00 \mathrm{~mm}$ wide. Anal lobes enlarged, sclerotised, each about $72 \mu \mathrm{m}$ long, $60 \mu \mathrm{m}$ wide; dorsal surface with 3 conical setae: inner anterior and inner posterior setae each $41 \mu \mathrm{m}$ long and outer setae $60 \mu \mathrm{m}$ long; ventral surface with 2 flagellate setae, 36 and $64 \mu \mathrm{m}$ long respectively; apical seta $185 \mu \mathrm{m}$ long. Medial plate absent.

Dorsum: setae conical numerous, each narrow, straight, with an acute apex, length varying from $24-75 \mu \mathrm{m}$, arranged in transverse bands on all segments, most abundant along submargin, but with 6 pairs medially in a longitudinal line in cephalic region. Macrotubular ducts symmetrical, numerous, present over entire surface, each $6 \mu \mathrm{m}$ wide, $12 \mu \mathrm{m}$ long, with an inner duct with a terminal gland. Microtubular ducts type B, each 5-7 $\mu \mathrm{m}$ long, $2 \mu \mathrm{m}$ wide, numerous throughout. Anal ring with 8 setae, each $101 \mu \mathrm{m}$ long, with a single row of pores.

Margin: setae undifferentiated from dorsal setae.

Venter: setae flagellate, numerous sizes varying from $24-77 \mu \mathrm{m}$ long, scattered throughout, arranged segmentally on abdomen. With 11 pairs of flagellate setae between antennae, of which 4 pairs each 84-96 $\mu \mathrm{m}$ and 7 pairs each 27-36 $\mu \mathrm{m}$ long. Enlarged setae $29-48 \mu \mathrm{m}$, numerous along margin. Suranal setae flagellate, $43 \mu \mathrm{m}$ long. Microspines not observed. Quinquelocular pores, each $5 \mu \mathrm{m}$ diameter, present near each spiracle and sparse on abdomen and near antennae. Cruciform pores present in cephalic region. Other type of pores not observed. Macrotubular ducts symmetrical, similar size to those on dorsum, present numerous along margin and sparse elsewhere; other macrotubular ducts with broad cup but narrow outer ductule, each
$2 \mu \mathrm{m}$ wide, $12 \mu \mathrm{m}$ long, numerous (about 20); present medially and laterally on abdominal segments. Microtubular ducts, type B, sparse throught. Legs well developed; lengths $(\mu \mathrm{m})$ : prothoracic coxae each 156; trochanter + femur each 277 ; tibia each 137, with five setae; tarsus each 105, claw 29, with a denticle; mesothoracic legs: coxa each 192, with ventral microspines; trochanter + femur each 281; tibia 144, with 4 setae; tarsus each 125; claw 36, with a denticle; metathoracic legs: each coxa 216, with microspines and 30-35 translucent pores (30 dorsal pores and 0-5 ventral pores); trochanter + femur each 312; femur with 5-6 marginal pores; tibia each 154, with 4 setae; tarsus each 134; claw 36 , with a denticle; claw and tarsal digitules of equal size, with slightly expanded apices. Antennae each $277 \mu \mathrm{m}$ long, with seven segments, III and IV of equal length, segment III without setae but all other segments with flagellate setae; fleshy setae present on apical 3 segments. Frontal lobes present, smaller than first antennal segment. Labium 3 segmented, $173 \mu \mathrm{m}$ long, basal segment with one pair of setae. Peritreme of spiracles $50 \mu \mathrm{m}$ wide. Anal tube unsclerotised.

Observations. This new species is described based on one specimen, in very good condition. The morphological characters were sufficiently different from other known species (see Comments below) to consider this specimen as an undescribed species.

Distribution. Brazil.

Comments. Acanthococcus papaveroisp. nov. resembles A.jorgenseni (Morrison, 1919), A. dubius and A. piptadeniae in having conical dorsal with acute apex. Based on the features of $A$. jorgenseni from the cotype examined and from Kozár and Konczné Benedicty (2008), A papaveroi sp. nov. differs from $A$. jorgenseni, in having (character-states of $A$. jorgenseni in brackets): (i) cruciform pores present in cephalic region (along margin), (ii) frontal lobes present (absent), (iii) microtubular ducts sparsely present throughout dorsal surface, but most numerous on thorax (sparse, never numerous), and (iv) anal lobes with two ventral flagellate setae (three ventral flagellate setae). Acanthococcus papaveroi sp. nov. differs from $A$. dubius in having (character-states of $A$. dubius in brackets taken from Miller and Miller, 1992): (i) dorsal setae arranged in transverse bands (in longitudinal bands), (ii) antennae with seven segments (six), (iii) frontal lobes present (absent), and (iv) prothoracic tibia with five setae (six). Acanthococcus papaveroisp. nov. differs from A. piptadeniae in having (character-states of $A$. piptadeniae in brackets taken from González and Claps, 2011): (i) metacoxae each with 30-35 pores (6-10 pores), (ii) microtubular ducts of one type only (two types), (iii) basal segment of labium with one pair of setae (two pairs), and (iv) anal lobes each with 2 flagellate setae ventrally (3 flagellate setae ventrally).

Etymology. The specific epithet, papaveroi, is dedicated to the Brazilian entomologist and scientist Dr. Nelson Papavero, in recognition of his important contributions to the development of science in the Neotropical region.

\section{Key to Acanthococcus species from Brazil}

(Modified after Foldi and Kozár, 2007; Kozár and Konczné Benedicty, 2008; González and Claps, 2011).

1. Ventral surface with very abundant, long flagellate setae, longest up to 130-135 $\mu \mathrm{m}$ long........... A. longisetosus (Foldi \& Kozár, 2007)

- Ventral surface with flagellate setae short to long, sparse to numerous, but each less than $100 \mu \mathrm{m}$ long...

2. Some dorsal larger setae arranged in a longitudinal medial band A. christopherus (Foldi \& Kozar)

- Some dorsal larger setae not arranged in a longitudinal medial band.

3. Dorsal setae numerous, with 20 or more setae across each posterior abdominal segments VI and VII; with a band of about 20 cruciform 
pores present between the anterior and posterior spiracles on each side .................................................. A. maximus (Foldi \& Kozár, 2007)

- Dorsal setae numerous but with fewer than 15 setae across of posterior abdominal segments VI and VII; without a band with cruciform pores between both pairs of spiracles ................................ 4

4- Posterior coxae with 6-12 translucent pores .....................................5

- Posterior coxae with 20-50 translucent pores .....................................8

5. Prothoracic tibia with 6 setae ..................................................................6

- Prothoracic tibia with 4-5 setae ...........................................................

6. Dorsal larger setae not arranged in medial longitudinal lines; microtubular ducts numerous on both surfaces; trilocular pores numerous in cephalic and thoracic regions and near spiracles....... A. piptadeniae(Hempel)

- Dorsal larger setae in medial longitudinal lines extending posteriorly as far as abdominal segment IV, absent on segments V-VII; microtubular ducts sparse, present only along margin on both surfaces; trilocular pores sparse, present medially in thoracic region and near spiracles. A. campinensis (Hempel)

7. Mediodorsal setae on posterior 3 abdominal segments very small; anal lobes sclerotized $A$. microspinus Kozár \& Konczné Benedicty

- Mediodorsal setae on posterior 3 abdominal segments equal in size to other dorsal setae; anal lobes membranous

.. Aenezuelaensis (Foldi \& Kozár)

8. Labium basal segment with 1 pair of setae .. .9

- Labium basal segment with 2 pairs of setae......................................... 10

9. Cruciform pores present in cephalic region; frontal lobes present; anal lobes each with 2 ventral setae................. A. papaveroi sp. nov.

- Cruciform pores present along margin body; frontal lobes absent; anal lobes each with 3 ventral setae........ A. jorgenseni (Morrison)

10. Quinquelocular pores present in a band of $40-50$ pores extending from each anterior spiracle to margin and in a group around each posterior spiracle; anal ring with a double row of pores.

A. lanatus (Hempel)

- Quinquelocular pores absent in a band extending from each anterior spiracle to margin and in a group around each posterior spiracle; anal ring with a single row of pores ...................................................11

11. Metacoxae each with grouped translucent pores; microtubular ducts sparse and only on dorsum., frontal lobes present A. perplexus (Hempel)

- Metacoxa with translucent pores not grouped; microtubular ducts present on both surfaces; frontal lobes absent $A$. dubius(Cockerell)

Comments. Acanthococcus dubius is extremely variable and may even be a complex of species (Miller and Miller, 1992). We consider, according with the two figures of this species presented by them, that the first segment of the labium has two pairs of setae and the frontal lobes are absent, to include it by these characters in the key. Acanthococcus coffeae is not included in the key because the original description by Hempel (1919) is very poor and does not provide characters to differentiate it from the rest of the species of the genus.

\section{Neotectococcus lenticularis Hempel, 1937 (Fig. 4)}

Type material. Brazil, Itatinga, in wild bush, 18/X/1935, Hempel coll. № 717. IB.

Material found but not examined. Collection DCMP, sample preserved in a test tube labeled: type (№ 124) and a slide with 8 females, São Paulo, on a wild plant.

Material examined. No data but labelled Neotectococcus lenticularis. 1 (8 adult females in good condition). MZSP.

Appearance in life. "The female constructs small lenticular galls on leaves of the host plant, the galls being somewhat concave on the underside. The galls have a circular shape, measure about $3 \mathrm{~mm}$ in diameter, have a small hole in the center on the underside, and the color a little lighter than the rest of the leaf" (Hempel, 1937).

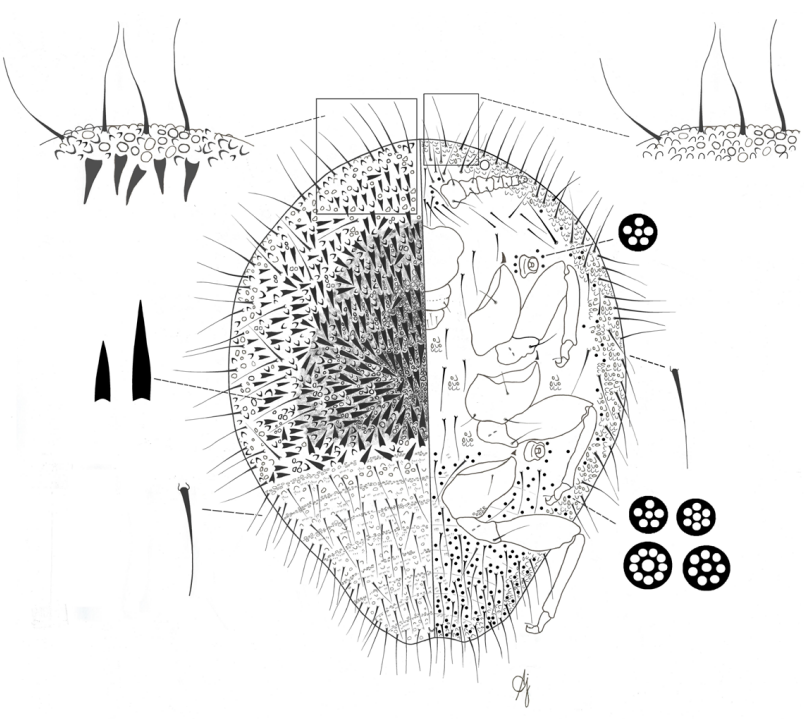

Figure 4: Neotectococcus lenticularis Hempel. Adult female.

Species diagnosis: medial and mediolateral dorsal areas sclerotised, with numerous papillae of different form and size, and two types of setae, anal lobes, macro- and microtubular ducts absent; legs well developed, very large and thick for body size.

\section{Redescription.}

Adult female (Fig. 4): body pyriform, about $0.80-1.19 \mu \mathrm{m}$ long, about $0.54-0.84 \mu \mathrm{m}$ wide. Anal lobes absent.

Dorsum: derm membranous, but with medial and medio lateral thoracic derm sclerotised, with numerous papillae of different form and size. Abdominal segments well defined by small papillae arranged in an intersegmental line across each segment. Dorsal setae of 2 types: 1) spinose setae, concentrated on medial and mediolateral thoracic regions, each straight or slightly curved with an acute apex, each about 19-36 $\mu \mathrm{m}$ long, decreasing in size towards body margins, and 2) flagellate setae each 46-60 $\mu \mathrm{m}$ long, arranged in transverse lines on abdomen. Macrotubular and microtubular ducts absent. Anal opening 9.6-12.0 $\mu \mathrm{m}$ wide; anal ring without pores or setae.

Margin: setae flagellate, each about 60-96 $\mu \mathrm{m}$ long, along margin, 3 or 4 setae on each abdominal segment.

Venter: derm membranous. Abundant small papillae on marginal and submarginal areas and scattered on the surface. Flagellate setae each 60-120 $\mu \mathrm{m}$ long, numerous on the surface, arranged in transverse lines on abdomen; but longest and sparser along submargin and in lateral areas of cephalic and thoracic regions; with 10-20 pairs of setae between antennae. Enlarged setae absent. Macro and microtubular ducts absent. Quinquelocular pores numerous across all abdominal segments, and also present laterally in meso- and metathorax and between antennae. Multilocular pores (apparently with 6, 7 and 9 loculi) scattered on abdomen. Legs very large and thick for body size; lengths $(\mu \mathrm{m})$ : prothoracic coxae each 108-156; trochanter + femur each 204-264; tibia 146-187; tarsus each 26-38, claw 17-19 $\mu \mathrm{m}$ long, with a slightly defined denticle; mesothoracic legs: coxae 144-151; trochanter + femur each 209-264; tibia 146--187; tarsus each 36-43; claw 19-21, with a slightly defined denticle; metathoracic legs: each coxa 144-192 long, with 8-10 translucent pores on distal apex trochanter + femur each 204-283; tibia 156-204; tarsus each 38-45; claw 19-21, with a slightly defined denticle; tarsal digitules not observed and claw digitules of equal size, with slightly expanded apices. 
Antennae each 144-198 $\mu \mathrm{m}$ long, with 7 segments, segments II and III longer and wider than other segments, flagellate setae present on all segments. Frontal lobes absent. Labium 3 segmented, 72-96 $\mu \mathrm{m}$ long, basal segment without setae, second segment with a single pair of setae and third segment with 3 pairs of setae. Peritreme of spiracles 19-22 $\mu \mathrm{m}$ wide. Anal tube unsclerotised.

Comments. The above redescription is based on eight adult females. The description by Hempel (1937) was subsequently repeated by Hodgson and Miller (2010). The present redescription of $N$. lenticularis differs from Hempel's description in having (character states from original description in brackets): (i) metathoracic legs with 8-10 translucent pores on distal apex (Hempel did not describe pores); (ii) antennae with setae present on all segments (Hempel stated "apparently without setae"); (iii) labium 3 segmented (Hempel did not mention the labium); (iv) vulva not observed (Hempel described it as being located between VI and VII segments); and iv) loculate pores absent on dorsum, present on ventral surface (present on both surfaces).

Other examined material

Acanthococcus jorgenseni(Morrison, 1919)

Cotype, Argentina, Misiones, xii/1910, on Myrcia apiculata, 1 adult female. USNM. In the label says “Myrica”-(see González and Carrizo, 2011).

Additional morphological characters after Kozár and Konczné Benedicty (2008): i) enlarged ventral setae numerous along margin and submargin ventral; ii) anal lobes with inner anterior dorsal setae longest, inner posterior and outer setae about same long; iii) microtubular ducts type $A$ and $B$ present on dorsum, absent on venter; iv) cruciform pores on submarginal and marginal bands along venter; v) macrotubular ducts symmetrical, similar in size to dorsal ducts present throughout and narrow ducts sparse on ventral abdomen.

\section{Acanthococcus perplexus (Hempel, 1900a)}

Brazil, Ipyranga, xii/1898, on Myrtaceae, Hempel coll. and det. № 95049 Type 1(1 adult female), Type 153 (crawlers), also dried material in tube with similar dates of collection. Bello Horizonte, Minas Gerais 10/vii/1899, on Jaboticabeira, A de Asais coll., A. Hempel det. № 95071(161), 1(3 adult females), also dried material in tube with similar dates of collection. Ipiranga, São Paulo, 30/X/1898, on wild plant, A. Hempel coll. and det. № 95082 (162), 1 (4 adult females), also dried material in tube with similar dates of collection.

Other dried material: Brazil, Estado de Bahia, 1921, on Goiabeira, G. Basidar col, Hempel det. № 95243 (172). All in MZSP.

This species was redescribed by Kozár and Konczné Benedicty (2008).

Acanthococcus piptadeniae (Hempel, 1937)

No data, but labelled Acanthococcus piptadeniaeHempel coll. R. 710. Gab.19, Div. 39, 1 (6 adult females + 1 first instar nymph) IB. This species was redescribed by González and Claps (2011).

\section{Apiococcus asperatus Hempel, 1900a}

Apiococcus asperatus. Type 147. Brazil, Ypiranga, on sapling of Myrtaceae 315, Hempel coll. 1(4 adult females in poor condition), MZSP. This species was included in the keys to species and galls by González and Claps (2013).
Lectotype. Apiococcus globosus. Type 148. Brazil, São Paulo, on shrub bark (Myrtaceae) Hempel. № 95.111 (1 adult female in good condition +1 second-instar nymph). MZSP. This species was redescribed by González and Claps (2013).

\section{Apiococcus gregarius Hempel, 1900a}

Lectotype and 3 paralectotypes. type 146. Apiococcus gregarious. Type 146. Brazil, Ypiranga, on Hempel coll. № 95109; on sapling of Myrtaceae, 2( 4 adult females + crawlers) MZSP.

This species was redescribed by Hodgson and Miller (2010) and included in the keys to species and galls by González and Claps (2013).

Apiococcus singularis Hempel, 1900a

Lectotype and paralectotype, Type 182. Apiococcus singularis. Brazil, Ypiranga, on sapling of Myrtacea, no date, Hempel coll. № 95104, 2 (2 adult females +crawlers) MZSP.

In a label says: Apiococcus singularis. Type 182. Female 19. In another label says: Apiococcus singularis Hempel. № 95.001 ( 2 adult females in regular condition), Brazil, Ypiranga, on sapling of Myrtaceae (Hempel, 1900a). MZSP.

This species was redescribed by González and Claps (2013).

Carpochloroides viridis Cockerell, 1899

No data, but labelled Carpochloroides viridis. Cotype. 7 (5 adult females + a lot of crawlers) 211. MZSP.

This species was redescribed by Hodgson and Miller (2010).

Hempelicoccus brasiliensis (Cockerell, 1900)

No data, but labelled Hempelicoccus brasiliensis. Cotype 1(11 adult females) № 95050. MZSP.

This species was redescribed by Hodgson and Miller (2010).

\section{Pseudotectococcus anonae Hempel, 1934}

Lectotype. Brazil, Vilcosa Est., Minas Gerais, 30/VIII/1933, on Annona sp., E.J. Hambleton coll. R. 374. Mounted from dried type material. R. 374; Paralectotype adult female (2): same dates, R. 374; Paralectotype crawlers (4), same dates, R. 374. IB.

This species was redescribed by Hodgson et al. (2004).

Pseudocapulinia lanosa Hempel, 1932

Brazil, Itarari, VIII/1928, host without date, Hempel coll., 4 (16) R.15. IB.

\section{Acknowledgements}

We thank the curators of the entomological collections from Brazil, Dr Carlos Lamas (MZSP) and Dr. Sergio Ide (IB), and two anonymous reviewers for important remarks and linguistic corrections of the original manuscript. This study was supported by the Consejo de Investigaciones de la Universidad Nacional de Tucumán, Argentina (Project G638/1).

\section{Conflicts of interest}

The authors declare no conflicts of interest. 


\section{References}

Caballero, A., González, P., Ramos Portilla, A. A., 2019. A new species of Acanthococcus Signoret and new records for Uhleria araucariae (Maskell) (Hemiptera: Eriococcidae). J. Insect Biodivers. 12 (1), 1-8.

Claps, L. E., 1993. Lista de tipos y cotipos de Coccoidea depositados en colecciones entomológicas de instituciones de Brasil. Scale 18, 2-12.

Evenhuis, N. L., 2018. The Insect and Spider Collections of the World Website. Available in: http://hbs.bishopmuseum.org/codens/ (accessed 12 June 2018).

Ferris, G. F., 1955. Atlas of the Scale lnsect of North America. Stanford University Press, Palo Alto. Vol. 7. The Families Aclerdidae, Asterolecaniidae, Conchaspididae, Dactylopiidae, and Lacciferidae.

Ferris, G. F., 1957. A review of the family Eriococcidae (Insecta: coccoidea). Microentomology 22, 81-89.

Foldi, I., Kozár, F., 2007. New species and new records of Eriococcus (Hemiptera: Coccoidea, Eriococcidae) from South America. Zootaxa 1573, 51-64.

García Morales, M., Denno, B. D., Miller, D. R., Miller, G. L., Ben-Dov, Y., Hardy, N. B., 2016. ScaleNet: A Literature-based Model of Scale Insect Biology and Systematics. Available in: http://scalenet.info (accessed 09 September 2018).

González, P., 2008. Two new species of Eriococcus(Hemiptera:Coccoidea: Eriococcidae) from the Andino Patagonica region of Argentina, with a key to the Eriococcus species of that region. Zootaxa 1899, 50-56.

González, P., Carrizo, J., 2011. Eriocóccidos (Hemiptera: Coccoidea) y sus hospederos en Argentina. In: VIII Convención Internacional sobre Medio Ambiente y Desarrollo. III Congreso sobre Manejo de Ecosistemas y Biodiversidad, 2011, La Habana, Cuba. Memorias. Cuba: Ministerio de Ciencia, Tecnología y Medio Ambiente, pp. 946955. Available in: www.cubambiente.com/es/general13 (accessed 09 September 2018).

González, P., Claps, L. E., 2011. Redescripción de una especie y descripción de dos especies nuevas de Acanthococcus Signoret (Hemiptera: Eriococcidae) de la región Neotropical. Rev. Bras. Entomol. 55 (2), 206-212.

González, P., Claps, L. E., 2013. El género Apiococcus Hempel (Coccoidea: Eriococcidae): redescripción de dos especies. Rev. Bras. Entomol. 57 (1), 19-23.
Hempel, A., 1900a. As coccidas brazileiras. Rev. Mus. Paul. 4, 365-537.

Hempel, A., 1900b. Descriptions of three new species of Coccidae from Brazil. Can. Entomol. 32, 3-7.

Hempel, A., 1919. Descripçao de duas novas especies de coccidas. Rev. Mus. Paul. 11, 451-457.

Hempel, A., 1932. Descripcão de vinte a duas species novas de coccideos (Hemiptera, Homoptera). Rev. Entomol. 2, 310-339.

Hempel, A., 1934. Descripcão de tres especies novas, tres generos novos e uma subfamilia nova de coccideos (Hemiptera, Homoptera). Rev. Entomol. 4, 139-147.

Hempel, A., 1937. Novas especies de Coccideos (Homoptera) do Brasil. Arq. Inst. Biol. 8, 5-36.

Hodgson, C. J., Gonçalves, S. J. M. R., Miller, D. R., Isaias, R. M. S., 2004. A key to genera of Eriococcidae (Hemiptera: Coccoidea) from the Neotropical region and a revision of Pseudotectococcus Hempel (Eriococcidae), a gall inducing scale insect genus from Brazil, with a description of a new species. Lundiana 5 (1), 51-72.

Hodgson, C. J., Isaias, R. M. S., Oliveira, D. C., 2013. A new gall-inducing genus and species of Eriococcidae (Hemiptera: Sternorrhyncha: Coccoidea) on Sapindaceae from Brazil. Zootaxa 3734 (3), 317-330.

Hodgson, C. J., Magalhães, V. M., Miller, D. R., 2011. Two new gall inducing genera and species of Eriococcidae (Hemiptera) on Malvaceae and Anacardiaceae from the Neotropics. Lundiana 10 (1), 53-72.

Hodgson, C. J., Miller, D. R., 2010. A review of the Eriococcid genera (Hemiptera: Sternorrhyncha: Coccoidea) of South America. Zootaxa 2459, 1-101.

Kondo, T., Gullan, P. J., Cook, L. G., 2016. A review of the genus Capulinia Signoret (Hemiptera: Coccoidea: Eriococcidae) with description of two new species. Zootaxa 4111 (4), 471-491.

Kozár, F., Konczné Benedicty, Z., 2008. Description of three new genera, five new species and some additional data on the taxonomy and distribution of Neotropic Eriococcidae (Homoptera: Coccoidea: Eriococcidae). Boll. Zool. Agrar. Bachic. Ser. II 40 (2), 117-144.

Miller, D. R., Gimpel, M. E., 2000. A Systematic Catalogue of the Eriococcidae (Hemiptera: Coccoidea) of the World. Intercept, Andover.

Miller, D. R., Miller, G. L., 1992. Systematic analysis of Acanthococcus (Homoptera: Cocoidea: Eriococcidae) in the Western United States. Trans. Am. Entomol. Soc. 118, 1-106. 